\title{
Becoming Michelle, a Contemporary Cultural Icon Decoding the Different Ways Leading from the South Side of Chicago to the White House
}

\author{
Flavia Cavaliere \\ Università degli Studi di Napoli Federico II \\ fcavalie@unina.it
}

\begin{abstract}
Mythological representations have always symbolically embodied human beings' ancestral fears and wishes. Yet today the reading of the languages of new myths can convey the key to an understanding of the historical period we are living in. Nowadays one of the most popular cultural icons is Michelle Obama. First Afro-American FLOTUS, Michelle is still serving as a highly influential role-model, whose recently published autobiography, Becoming, is a record best-selling book. By drawing on the theoretical approach of Appraisal Framework (Martin and White 2007), I intend to investigate how her 'becoming Michelle' was accomplished. The AF explores the way language is used to evaluate and/or adopt stances and to construe textual personas, and how affective involvement can be conveyed through a set of indicators. Accordingly, qualitative examples are analysed to show how, in Michelle's autobiography, the lexico-grammar options are significant in the process of the shaping of her status of a modern cultural icon.
\end{abstract}

\section{Keywords}

Cultural icon; Michelle Obama; Autobiography; Appraisal Framework

\section{Sommario/Content}

1. $21^{\text {st }}$ Century Myths

2. Construing a Most Compelling Icon of Our Times: Michelle Obama

3. Appraising Michelle's Discursive Voice

4. Concluding Remarks

References 


\section{Ocula}

Vol 21, No 22 (April 2020) • DOI: 10.12977/ocula2020-9

Flavia Cavaliere | Becoming Michelle, a Contemporary Cultural Icon. Decoding the Different Ways Leading from the South Side of Chicago to the White House

\section{1. $21^{\text {st }}$ Century Myths}

The intertwining nexus among people(s) and/or socio-cultural events has always been represented through (symbolic) images (Pestell and Palazzolo 2016), as Maalouf argues: "Tout, dans l'Histoire, s'exprime par des symbols» (1998: 99). In particular, through archetypical and mythological representations, human beings have symbolically embodied both their own ancestral dreads and wishes. ${ }^{1}$ Though myths have been widely interpreted in conflicting ways, such as collective dreams, the outcome of a kind of aesthetic play, or the foundation of ritual (Lévi-Strauss 1955: 428), they are in fact mostly seen as misrepresentations and/or transformations of somehow historical events and characters, and they have been considered projections of mankind's most inner psychological conflicts throughout history. Therefore, the investigation of mythological creations and their diverse representations and/or narrations has enabled mankind to trace back the different ideals, aspirations, and taboos generated in and by different socio-cultural scenarios (von Franz 1989). Still, in modern times, mythemes (Lévi-Strauss 1963) are recognized as a great Wirksamkeit in influencing people's decisions and choices and play a pivotal role in therapeutic settings (Hillman 2007). In many cases, archaeological, anthropological, and philological discoveries have also shown how many fundamental myths can be regarded as timeless, since they may also occur with important similarities even in peoples who - either from a geographical or a historical point of view - seem to be disconnected. Even if, in both diachronic and synchronic perspectives, mythemes and their narratives - together with names, skills, attributes, situations, settings, etc. - have predictably been largely altered in different latitudes and historical moments, some common patterns and a fundamental common core are always preserved, and even when this «nucleus of ideation» (Cobos 1991) appears somehow modified, evidence of its enduring survival is still clearly discernable. Old myths of culture - often re-fashioned through a process of an alteration/modification of (multimodal) meanings, namely a «re-semiotization $»^{2}$ (Iedema 2003: 29-57) - have nowadays been reinterpreted and substituted with apparently newer and more historically appropriate cultural models, or better, cultural icons.

In various contexts, and for different reasons, some real and/or fictional characters (may) become cultural icons, i.e. our $21^{\text {st }}$ century myths. «The sys-

1 Let us remind ourselves, to quote but one example, of how ancient people(s) often projected their fears in various mythical scenarios where cosmic forces were anthropomorphized and, literally, made everything collapse through menacing flashes of lightning and rumbles of thunder.

2 Re-semiotization is made possible by the complementary processes of 'transformation' and 'transduction', which, according to Kress, account for the purposive reshaping of semiotic resources within and across modes. More specifically, along with Kress's theoretical formulation, the co-operation of transformation «operates on the forms and structures within a mode» while transduction «accounts for the shift of 'semiotic material' [...] across modes» (2003: 36). For further research on the topic see also Kress and van Leeuwen 2006; Prior and Hengst 2010. 


\section{Ocula}

Vol 21, No 22 (April 2020) • DOI: 10.12977/ocula2020-9

Flavia Cavaliere | Becoming Michelle, a Contemporary Cultural Icon. Decoding the Different Ways Leading from the South Side of Chicago to the White House

tem of vital tensions to which a people are subjected is translated as an image [...]. In this new image that bursts onto the scene we can see the avatars of old myths rejuvenated by the changes in the social landscape - a landscape to which people respond according to the demands of the times» (Cobos 1991). Hence, today, the reading of the verbal and/or non-verbal languages of new myths can still provide the key to an understanding of the current historical period we are living in.

Nonetheless, while the concept of an iconic image is easily understood, what the adjective cultural stands for is possibly harder to define. In today's scenarios, where it is anything but easy to find and outline neat, clear-cut (socio-) cultural categories, the conventional «culture concept seems perhaps more contested, or contestable than ever» (Hannerz 1996: 30), and accommodation to new identities and languages are continuously required. In our web-wired and fast-moving global village, new communication patterns (in particular, synchronous and asynchronous communication tools) have unquestionably involved deep changes in attitudes and affected our lives forever. "When the image of Nelson Mandela may be more familiar to us than the face of our nextdoor neighbour, something has changed in the nature of our everyday experience» (Giddens 2002: 11-12). The concept of a monolithical cultural identity, which typically drew on Herder's vision of «cultures as closed spheres or autonomous islands, each corresponding to a folk's territorial area and linguistic extent» (Welsch 1999: 195), definitely seems to be being questioned, and cultures appear as interconnected systems of ethics, as interactive platforms of hybrid lifestyle rules and customs, where fragmented mind-style trends and evolving concepts mingle. As a matter of fact, one of the key features of late modernity is the concept of the fluidity of culture(s) (Bauman 2000), an understanding of which is an active factor in our cultural life: «There is now a world culture, but we had better make sure we understand what this means: not a replication of uniformity but an organization of diversity, an increasing interconnectedness of varied local cultures, as well as a development of cultures without a clear anchorage in any one territory» (Hannerz 1996: 202).

Within this ever-changing cultural scenario, the interpretation and construal of cultural icons become more difficult, since their relevance and influence in a given culture may depend on too many and volatile issues. Additionally, nowadays, myths are not simply defined by the content of their underlying messages, but rather by the ways, or modes, ${ }^{3}$ in which such messages may be variously transmitted (oral/written discourse, cinema, photography, advertising, etc.) and then decoded as semiological systems where given (ideological) values are, so to say, promoted. Nonetheless, these days, peoples, regardless of their current cultural displacement, are all still looking for «dynamic images that impel behavior in a particular direction» (Cobos 1991), which are basically the core element of myths of all times.

3 Jewitt defines modes as «any organized, regular means of representation and communication, such as still image, gesture, posture, and speech, music, writing, or new configurations of the elements of these» (2009: 184). 


\section{Ocula}

Vol 21, No 22 (April 2020) • DOI: 10.12977/ocula2020-9

Flavia Cavaliere | Becoming Michelle, a Contemporary Cultural Icon. Decoding the Different Ways Leading from the South Side of Chicago to the White House

Within this perspective, one of today's most powerful people who is most widely recognized as a mythological creature is unquestionably Michelle LaVaughn Robinson, maybe better known with the surname of her husband, Barack Obama, the $44^{\text {th }}$ President of the USA. In April 2019, Time Magazine revealed its annual list of the 100 most influential people in the world, in which Michelle Obama was included and listed as an Icon (Barr 2019). As is well known, entrants - chosen from across the globe - are introduced in the magazine's annual list by other high-profile figures, with whom they share a close relationship. Michelle Obama's blurb was written by her friend Beyoncé Knowles-Carter, another role model herself. In her tribute, the Grammy Award-winning musician praises Michelle Obama - «a warm, regal, confident woman» - not only because during her tenure in the White House «she also used her position of power to improve the world around her», but most of all because «She empowers all of us to interrogate our fears and surpass greatness» (Knowles-Carter 2019). Knowles-Carter's words offer a precise description of (what is inscribed in) the grammar of myths: not only do they enable one to make sense of one's experiences within a culture, but above all they allow one «to organize shared ways of conceptualizing something within a culture» (Lakoff and Johnson 1980: 185-6).

My study of Michelle Obama as a cultural icon aims to reveal how certain values, attitudes and beliefs of hers are linguistically supported in her bestselling autobiography Becoming.

\section{Construing a Most Compelling Icon of Our Times: Michelle Obama}

Michelle LaVaughn Robinson was definitely under the global spotlight on 20 January 2009, the day her husband Barack Obama was sworn in as the $44^{\text {th }}$ President of the United States of America (CNN 2009).

That day she became the first Afro-American to serve as FLOTUS (First Lady Of The United States Of America), so, in her recently published memoir, Becoming, Michelle writes, «I was 'other' by default» (2018: 284). ${ }^{4}$ Nonetheless, even though she had initially been "dismissed early on by some critics as an angry black woman unsuited for the tradition-bound role of first lady» (Davis 2016), Michelle LaVaughn Robinson was soon to become one of the most influential and iconic women of our era.

Yet, none of the First Ladies who preceded her were from such an underprivileged background as the one she came from. Not only were most of them from extremely wealthy families - like Ida McKinley, the daughter of James Saxton, a prominent Canton banker - but some of them - like Martha Washington and Julia Grant - were even slaveholders. Michelle has always been aware that «If there was a presumed grace assigned to my white predeces-

4 Henceforth words, phrases and sentences in italics will signal examples or excerpts taken from Michelle Obama's autobiography (Obama 2018), while numbers in brackets indicate their corresponding pages. 


\section{Ocula}

Vol 21, No 22 (April 2020) • DOI: 10.12977/ocula2020-9

Flavia Cavaliere | Becoming Michelle, a Contemporary Cultural Icon. Decoding the Different Ways Leading from the South Side of Chicago to the White House

sors [...] I knew it was not likely to be the same for me. [...] My grace would need to be earned [...]. I stood at the foot of the mountain, knowing I'd need to climb my way into favor» (284).

From the very start of her public appearances, she was well aware that all her words and gestures would be held to a different standard. Though she never sought out public life herself, her life was changed forever on a summer day in 1989 when, ten minutes late, an intern whom Michelle was assigned to mentor while practising law at Sidley Austin LLP, a corporate law firm in downtown Chicago, entered her room. Although (or possibly because) they were totally different from one another, after dating for three years the two got married, and then had to cope with long and straining periods of separation due to school and/or work.

Detailed stories about Michelle Obama's life and her family are narrated in her autobiography Becoming, a book which has been setting records since its publication on 13 November 2018. In its first day it sold around 725,000 copies in the United States and Canada; fifteen days after publication, with 1.4 million copies sold in the US alone, Becoming broke other sales records, making it both the second best-selling debut for any book in 2018 and the best-selling US book for the year 2018 (BBC 2018). Translated into twenty-four languages, Becoming topped bestseller charts worldwide as well, in countries including Australia, the UK, France, Germany, Korea and South Africa. By 26 March 2019, Becoming had sold 10 million copies (BBC 2019), and it may be the most successful memoir of all time.

Since the publication of Recollections of Full Years in 1914 by Helen Taft, the $27^{\text {th }}$ FLOTUS, with the exceptions of Pat Nixon and Jacqueline Kennedy Onassis, every First Lady has published a memoir (Anthony 2016). Conventionally, these books were mainly meant to exalt and celebrate their husband's programme and work. In Becoming, instead, in simple though evocative language, Michelle describes herself as «an ordinary person who found herself on an extraordinary journey» (420-421), from her one-bedroom apartment on Euclid Avenue in the South Side of Chicago to the most famous address in the world, «a place with more stairs than I can count - plus elevators, a bowling alley, and an in-house florist» (ix).

The book, which is subdivided into three sections - Becoming Me, Becoming Us and Becoming More -, ultimately confirms Michelle's unpretentious image as an independent-minded woman. The first part starts as an almost typical story of African American life and ambition: "When I was a kid my aspirations were simple. I wanted a dog. I wanted a house that had stairs in it - two floors for one family. I wanted a four-door station wagon» (ix). Nevertheless, though born with a low socioeconomic standing, Michelle recalls a mostly happy childhood filled with rock-solid family love. Thanks to her parents' guidance and values, she learned how to be unafraid and outspoken. As Michelle recounts, her mother Marian, who chose to stay at home to care for her kids, "showed me how to think for myself and to use my voice» (xi). Her father Fraser, though diagnosed with multiple sclerosis in his thirties, never missed a single day at work and was a source of emotional and intellectual 


\section{Ocula}

Vol 21, No 22 (April 2020) • DOI: 10.12977/ocula2020-9

Flavia Cavaliere | Becoming Michelle, a Contemporary Cultural Icon. Decoding the Different Ways Leading from the South Side of Chicago to the White House

guidance and support who taught Michelle «to work hard, laugh often, and keep my word» (x).

More importantly, «Together, in our cramped apartment on the South Side of Chicago, they helped me see the value in our story, in my story, in the larger story of our country» (x). In the book, even though the progression of the Obamas' vision and then ambitions - which crystallized into a Senate campaign, and then a Presidential one - can be easily traced, stories from political Washington are largely glossed over in favour of topics like worklife balance, exercise and, most of all, female solidarity. Michelle continuously emphasizes the daily concerns of any (Afro) American, particularly women, to juggle everything in their busy schedule. She tells the reader about her experiences as a working mother and her everyday difficulties of balancing the duties/problems of marriage, infertility and parenthood. She narrates the physical and emotional strain of her miscarriage and the in vitro fertilization treatments she underwent to conceive her daughters. Then, once First Lady, she expresses her concerns for the safety of her children who, since becoming globally recognized, were leading a life that was privileged but also in which they were constantly surrounded by «Secret Service agents, with their earpieces and guns» (xi). Though she deplores that «It seemed that my clothes mattered more to people than anything I had to say» (332), she learned pretty quickly how to manage her public appearance and iconicity and, most of all, how to "reframe it as an opportunity» (332). Her world-famous vegetable garden in the White House grounds, for instance, was meant as a cunning way to lecture America about healthy eating and, more particularly, to reduce childhood obesity, as advocated by 'Let's move', one of the many public campaigns led and promoted by Michelle Obama.

Biographical memories and recollections reported in the book, however, are not significant in themselves, but introduce (some) of the most relevant notions which made Michelle such a highly influential role-model.

By drawing on the theoretical approach of Appraisal Framework (Martin and White 2007), ${ }^{5}$ my paper aims to investigate how her 'becoming Michelle' was accomplished. The key notions on and through which Michelle's iconicity is mainly rooted and conveyed are empowerment and mentoring together with a pro-active optimism; these notions are basically communicated/shared through physicality which, in turn, enhances relatability. It is principally relatability - together with her attitude of normalcy in a life that was, and still is, definitely far from being ordinary - which is generally considered Michelle's main appeal. «During her time in the White House, Obama grew into a symbol for rejecting the cool distance inherent to symbolism; she was the First Lady to court an air of relatability, and she retained it even as she became one of the most popular Americans in history» (St. Félix 2018).

5 The Appraisal Framework, as theorized by Martin and White, will be introduced in the following section. Nonetheless, an in-depth explanation of the Appraisal Framework System is available at the Appraisal Website's homepage: <http://www.grammatics.com/appraisal> (last updated: 27/12/2015). 


\section{Ocula ${ }^{22}$}

Vol 21, No 22 (April 2020) • DOI: 10.12977/ocula2020-9

Flavia Cavaliere | Becoming Michelle, a Contemporary Cultural Icon. Decoding the Different Ways Leading from the South Side of Chicago to the White House

If we agree that «meaning is always permeated with value judgement» (Voloshinov 1929/1973: 105), my study intends to highlight, through an Appraisal Framework (AF) analysis of some qualitative examples, how, in Michelle's autobiography, the above-mentioned notions are voiced through specific lexico-grammar options which become significant to the process of making her own persona and, in turn, influence the shaping of her status as a modern cultural icon.

\section{Appraising Michelle's Discursive Voice}

\subsection{Introducing the Appraisal Framework}

A short introduction to the main analytical tools of the Appraisal Framework may be useful before analyzing (some) qualitative examples of Michelle's lexico-grammatical choices and modes of textuality. Nonetheless, only some preliminary hints will be provided in this paper.

The Appraisal Framework (AF) was developed in the early $1990_{\mathrm{s}}$ by Professor Jim Martin and his research team based at the University of Sydney as an extension of M.A.K. Halliday's Systemic Functional Linguistics theories within a wider literacy project, which aimed at defining the attitudinal values by which texts apply social norms to evaluate human behaviour (Martin and White 2005, 2007). More precisely, the AF system enables us to investigate/highlight:

- the ways in which language is/can be used to express or evaluate situations;

- how speakers/writers negotiate these attitudinal and other types of positionings with actual or potential dialogic partners;

- how attitudes and emotive factors are conveyed;

- how/which rhetorical strategies are used to adopt (c)overt stances.

Accordingly, the AF comprises three major interactive subsystems: Engagement, Gradation, and Attitude.

In 'Engagement', all utterances are dialogistic because all texts are to be considered as a dialogue in which speakers/writers engage with other speakers/writers, or with which they anticipate possible responses.

'Gradation' is concerned with grading or scaling, either in terms of the interpersonal Force which the speaker attaches to an utterance, or in terms of the preciseness or sharpness of Focus with which an item exemplifies a value relationship.

'Attitude' evaluates the speakers' positive/negative assessment of people, places, things, states of affairs and her/his associated emotional/affectual responses. An attitudinal position is often evoked not by single words (though individual words can be attitudinal) but by phrases or complete stretches of language and, above all, by the interaction of diverse elements of the statements which transmit the writer's propositions and points of view and which, therefore, must be analyzed as a whole. 


\section{Ocula ${ }^{22}$}

Vol 21, No 22 (April 2020) • DOI: 10.12977/ocula2020-9

Flavia Cavaliere | Becoming Michelle, a Contemporary Cultural Icon. Decoding the Different Ways Leading from the South Side of Chicago to the White House

Attitudinal Positioning, in turn, may express positive and negative evaluations involving:

i. Affect

ii. Judgement

iii. Appreciation

The following section will focus on some qualitative examples which highlight how, in Becoming, intentional and pragmatic uses of lexico-grammatical choices and modes of textuality, by fitting this three-sectional attitudinal schema, confirm and reinforce the main aspects on which Michelle's iconicity is grounded.

\begin{tabular}{|c|c|c|c|}
\hline \multicolumn{3}{|l|}{ AF System } & \multirow{2}{*}{$\begin{array}{l}\text { Examples from Becoming } \\
\text { «I was beginning [...] feeling more } \\
\text { and more open and optimistic» } \\
(269)\end{array}$} \\
\hline Affect & $\rightarrow$ & $\begin{array}{l}\text { is concerned with emotional reactions } \\
\text { and disposition }\end{array}$ & \\
\hline Judgment & $\rightarrow$ & $\begin{array}{l}\text { evaluates human behaviour, either } \\
\text { positively or negatively, by reference } \\
\text { to a set of institutionalized norms, and } \\
\text { is subdivided into 'social sanction' and } \\
\text { 'social esteem'* }\end{array}$ & $\begin{array}{l}\text { «The political world was no place } \\
\text { for good people» (236) }\end{array}$ \\
\hline Appreciation & $\rightarrow$ & $\begin{array}{l}\text { concerns positive and negative assess- } \\
\text { ments of material objects (artefacts, } \\
\text { works of art, texts, processes, and so } \\
\text { on) }\end{array}$ & $\begin{array}{l}\text { «A miniature Eden in progress } \\
\text { made up of spiralling young ten- } \\
\text { drils» }(328)\end{array}$ \\
\hline
\end{tabular}

* Social sanction concerns some set of rules or regulations, more or less explicitly codified by the culture at stake, whereas social esteem involves questions of legality and morality and can be evaluated according to 'veracity' and 'propriety'. Social esteem is further subdivided into three subcategories: 'normality', 'capacity', and 'tenacity'. The full Judgement system is viewable at <https://www.grammatics.com/appraisal/appraisaloutline/framed/appraisaloutline-10.htm $>$.

Table 1. Examples from within the three-sectional attitudinal schema.

\subsection{Evaluating Some Detailed Examples}

Before analyzing some qualitative examples, a preliminary distinction needs to be made between the 'interactive' level and the 'autonomous' level (Hunston and Thompson 2000; Abbamonte and Cavaliere 2006) of the whole text. At an 'autonomous' level, informative terminology and neutral attitudes are more commonly found, while the 'interactive' level reveals the author's more subjective and personal comments and his/her evaluative attitude towards the topic in question. In Becoming, an interactive plane is clearly at work since, with a few noticeable exceptions, the author's strongly committed voice is loudly audible throughout the whole book. Michelle's communication always deploys along an 'affective' plane where her lexico-pragmatic choices evidently also express her emotive and socio-political commitment. In terms of the authorial presence, in fact, the writer's evaluative attitude to the subject matter is always explicit and apparent, often through informal and matter-offact language - You really gotta do that? (80); live-and let-live slogan (251); 


\section{Ocula}

Vol 21, No 22 (April 2020) • DOI: 10.12977/ocula2020-9

Flavia Cavaliere | Becoming Michelle, a Contemporary Cultural Icon. Decoding the Different Ways Leading from the South Side of Chicago to the White House

Nope (276); pissed-off harpy (315), etc. - where idiomatic expressions are not infrequent - we lived above the shop (346).

The more formal stylistic choices, instead, stand for a more neutral distant attitude, and mainly belong to pages devoted to accounts of the presidential campaign or descriptions of Planet Politics (267). The prevailing use of more 'informal' terms involves the readers in a more direct and explicit manner, allowing them to share in the concepts that are discussed. These lexical choices are all in line with Michelle's relatability, the very first essence of her iconicity; she herself maintains "I cared what people thought» (258). From a stylistic point of view, relatability is also enhanced thanks to a dialogistic mode, which is literally audible from the very first lines. Michelle directly addresses readers, «What was happening to us?» (216), who also feel continuously involved thanks to direct speech - «I'm serious, she said» (80) - and direct questions - «Are you what you appear to be?» (41). These and countless other examples all contribute to engage the reader in a vis-à-vis, somehow strictly confidential, relation with the author. In addition, Michelle very frequently indulges in narrating episodes where she stresses her «normalcy» (217) or how her «family was on the poor side of the neighborhood spectrum» (21). Readers are reminded to «see Barack as human and not as some otherworldly savior» (241) and «the Queen as human as the rest of us» (317) (Explicit Positive Judgement).

Therefore, she even publicly spoke about how her husband did not pick up his socks or sometimes snored in his sleep (236), and described her first encounter with Queen Elizabeth II as follows: «Forget that she sometimes wore a diamond crown and that I'd flown to London on the presidential jet; we were just two tired ladies oppressed by our shoes [...] I laid a hand affectionately across her shoulder» (318). Media reports harshly criticized her behaviour on such occasions, though she was simply demonstrating once again her genuine spontaneity and unaffected moods. The episode with the Queen, in particular, combines two of the main aspects on which Michelle's iconicity is grounded, namely the above-mentioned relatability and her physicality, which are strictly intertwined. Michelle shows her relatability also by means of physical contact (even when this may sometimes entail a breach in protocol) while, in turn, her physicality literally shows and expresses her empathy and being in touch with people, hence recalling again her relatability.

Lexical choices, where bodily experiences are vividly evoked, engender an empathic, almost physical participation, where (all) senses are stirred. Readers are invited not simply to know about her life but to watch, or better, take part in it. In this perspective, hypotyposis is one of the most frequently chosen rhetorical tools.

At the denotative level, linguistic options aim to make visual experiences more evident, particularly through:

- very detailed or vivid descriptions: «a hardy historic copper-mining town set down in the brushy southwestern corner of Montana, with the dark ridgeline of the Rocky Mountains visible in the distance» (251); «I saw the lightness in his smile» (256); 


\section{Ocula ${ }^{22}$}

Vol 21, No 22 (April 2020) • DOI: 10.12977/ocula2020-9

Flavia Cavaliere | Becoming Michelle, a Contemporary Cultural Icon. Decoding the Different Ways Leading from the South Side of Chicago to the White House

- long, exhaustive lists of objects: «some balloons, a grocery-store cake, ten candles and a tub of ice cream» (272);

- an accumulation of events and characters and/or objects: «the man with a seed-corn logo on his breast pocket, the college student in a black-andgold pullover, the retiree who'd brought an ice cream bucket full of sugar cookies she'd frosted with our rising-sun logo» (237).

These intentional lists enable the recipient to more easily establish both a mental and visual engagement, since the author's main purpose seems to be to 'make readers feel' the described scene(s). More specifically, Michelle wants readers to hear her voice, which, not surprisingly, is one of her most commonly recurring terms, since in her life she has learned «the power of using your voice» (16, insert). Therefore, not only does the author describe the setting of scenes, but she also frequently evokes their sounds as well:

«... the summer sun finally dropping behind the western mountains, the sound of firecrackers beginning to pop in the distance» (271).

And still many other possible examples, like:

«There's the sound of that scraping in the early mornings - the hack hack hack of it» (51).

"I could hear it almost in the pulse of the applause. More of this, More of this, More of this ${ }^{6}(216)$.

«... her laugh was a cackle» (268).

Intense physical sensations are described as well:

«I remember the jet engines firing, shockingly loud. And then we were rattling down the runway and beginning to tilt upward as the acceleration seized my chest and pressed me backward into my seat» (60).

Script and scene(s) are activated contemporaneously, especially when the readership is culturally grounded in the same way, as it manages to evoke a shared, concrete and intense image.

This physical involvement also becomes highly instrumental for enhancing and emphasizing Michelle's above-mentioned relatability, and it is another rhetorical way to achieve a close(r) author-reader relationship.

Other aspects which, according to Michelle, emerge as fundamental in one's life are being a determined individual, as well as having caring and dedicated motivators and mentors. Since she was a very young kid, Michelle has proven to be an extremely confident, strong-willed and determined person, as the examples (see underlined verbs and adjectives in particular) in Table 2 demonstrate.

6 Italics used for emphasis in the original version. 


\section{Ocula}

Vol 21, No 22 (April 2020) • DOI: 10.12977/ocula2020-9

Flavia Cavaliere | Becoming Michelle, a Contemporary Cultural Icon. Decoding the Different Ways Leading from the South Side of Chicago to the White House

\begin{tabular}{ll}
\hline EXAMPLES FROM THE TEXT & ATTITUDINAL POSITIONING \\
$\begin{array}{l}\text { I was about four when I decided to learn } \\
\text { piano (8) }\end{array}$ & Social Esteem Positive Explicit Capacity \\
$\begin{array}{l}\text { I was confident about my ability to read (17) } \\
\text { Ijust wanted to achieve. }\end{array}$ & Social Sanction Explicit Negative Propriety \\
$\begin{array}{l}\text { Or maybe I didn't want to be dismissed as } \\
\text { incapable of } \underline{\text { achievement }}(18)\end{array}$ & \\
$\begin{array}{l}\text { I was a box checker }- \text { marching to the } \\
\text { resolute beat of } \underline{\text { effort/result, effort/result }}\end{array}$ & Social Esteem Positive Explicit Capacity \\
(89) & Positive Affectual Positioning
\end{tabular}

Table 2. Examples of positive affectual positioning and semantic areas of volition.

Michelle's affectual positioning is mainly conveyed through:

- verbs indicating both mental and physical processes which, literally and/ or metaphorically, indicate her willpower, determination and effort, such as want, work, endure, promote, act, achieve, and empower (see also Table 3);

- adverbs of manner: successfully, dutifully, diligently;

- adjectives/nouns: confident, control freak, effort, challenge;

- recurrent nominalizations of terms such as achievements, actions, approval, accomplishments, and results.

Throughout her whole life, she never takes any of her achievements for granted, and throughout Michelle's narration, from high school to the White House, readers are urged to be proactive and dynamic in their actions and decision-making processes, following her life-long mantra «which could be filed under one

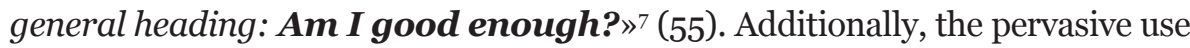
of verbs like work, achieve and other semantically-related terms all convey the inevitable necessity of a strong, even physical commitment, in order to avoid failure, as is also confirmed by sentences like the ones reported in Table 3.

\begin{tabular}{ll}
\hline EXAMPLES FROM THE TEXT & ATTITUDINAL POSITIONING \\
\hline work hard & \\
$\quad$ - to be seen & \\
$\quad$ - to find their voices & Explicit Positive Judgement \\
- just to learn & \\
push back against stereotypes & \\
fight the invisibility & \\
\hline
\end{tabular}

Table 3. Examples of Explicit Positive Judgement concerning hard working.

Michelle repeatedly stresses the fundamental importance of role models (particularly for young women of colour) and mentors who can fuel one's life ambitions. In particular, she recounts how when she announced her interest in applying for Princeton University to her college counsellor, she got pain-

7 Italics used for emphasis in the original version. 


\section{Ocula ${ }^{22}$}

Vol 21, No 22 (April 2020) • DOI: 10.12977/ocula2020-9

Flavia Cavaliere | Becoming Michelle, a Contemporary Cultural Icon. Decoding the Different Ways Leading from the South Side of Chicago to the White House

fully stuck on her dismissive judgement «I'm not sure that you're Princeton material» (66). Nonetheless, she states «I was not going to let one person's opinion dislodge everything I knew about myself» (66). This is because her parents had taught her never to lower her gaze and they had always been her and her brother's foremost motivators, as can be easily elicited by the positive pragmatic force of their encouragements to «keep moving forward» (14), «just go and do your best» (21) and «transcend [...] get yourself further» (40). They also drummed the positive values of education and competition into their children, as the examples in Table 4 show.

\begin{tabular}{ll}
\hline EXAMPLES FROM THE TEXT & ATTITUDINAL POSITIONING \\
\hline$-\quad$ [they] appreciated seeing strong people excel (5) & \\
$-\quad$ show what a good education could yield (25) & \\
$-\quad$ had drilled us under the importance of using & Explicit Positive Judgement \\
$\quad$ proper diction (40) & \\
\hline
\end{tabular}

Table 4. Evaluating competition and education.

This is why empowerment appears to be paramount in life, and she keeps repeating «Failure is a feeling long before it becomes an actual result» (43, 66) (Explicit Negative Judgement).

The importance of empowerment is also clearly reflected in Michelle's slogans, such as «Work to Create the World as It Should Be», or «When They Go Low, We Go High».

Furthermore, Michelle's self-determination and hard work are, and have always been, always backed by her own optimistic view. In her life, she always «liked to joke around» (269) and she inherited from her family a «long-standing habit in blocking out bad news» (14), which couples her and her husband's «buoying faith that if you stuck to your principles, things would work out» (153).

Following the FrameNet approach, ${ }^{8}$ the conceptual frame - where frames encode a certain amount of 'real-world knowledge' in a schematized form (Lowe et al. 1998: 2-3) - of promoting positive changes is built up through recurrent:

- adjectives/nouns: change, difference/different;

- phrases such as «the idea of change» (264); «people are hungry for change» (260); or «delivering real change» (259);

8 FrameNet is a corpus-based computational lexicography project based on Fillmore's theory of frame semantics, which he initially developed in the 1970s. Housed at the International Computer Science Institute in Berkeley, California, the FrameNet project aims to provide for a significant portion of the vocabulary of contemporary English a body of semantically and syntactically annotated sentences from which reliable information can be reported on the valences or combinatorial possibilities of each item targeted for analysis. In 2001, Fillmore and Baker finalized the FrameNet method, which identifies the following sets: a set of words with a semantic congruence; a set of patterned co-texts identified from a corpus; semantic roles appropriate to the set; and a mapping of the roles onto the patterns (Fillmore and Baker 2001). 


\section{Ocula}

Vol 21, No 22 (April 2020) • DOI: 10.12977/ocula2020-9

Flavia Cavaliere | Becoming Michelle, a Contemporary Cultural Icon. Decoding the Different Ways Leading from the South Side of Chicago to the White House

- nominalizations of terms such as achievements, actions, approval, accomplishments, or results.

Optimism is conveyed through the frequent use of adjectives like high-spirited (43), smiling, heartening (291), happy, mirthful (306), and startling (307) - to quote but a few - and phrases like «The optimism was big and it was energizing. [...] Hope is making a comeback» (259).

Indeed,

formulaic patterns acquire discursive relevance in terms of their ability to homogenize discourse which, in turn, provide stylistic cohesion. More importantly, [...] formulaic patterns are generative of a discourse. The ideological significance of such lexicalization comes to the fore when we realize to what extent these patterns of repetition concur to build up a defined context. (Cavaliere 2012: 97)

Accordingly, the frequent repetition of many words/phrases, which allocate and collocate to the perception of Change and Optimism as the main frame semantics, contribute to conveying the author's faith in the transitivity of intervention and positive changes, and in turn enhance a chain reaction-like response in the reader(s) who is actively called into (re)action. Within this perspective, the gist of Michelle's optimistic view is basically the scaffolding onto which Barack's slogan YES WE CAN was built on. ${ }^{9}$

\section{Concluding remarks}

In Becoming, Michelle narrates and represents herself through frame elements, and their syntactic realizations (i.e. grammatical functions, phrase type and other syntactic elements) all contribute to a creative linguistic process where the $21^{\text {st }}$ century cultural icon manages to engage readers in an overall sensation of involvement and participation.

Myths were once associated with heroes and their deeds, but then Barthes (1957) showed us how they had actually become the dominant ideologies of modern times. Today's myths, similarly to metaphors, help us to experience our world and construe it. On the one hand, Michelle Obama embodies and epitomizes most of the positive values and beliefs of our century and, as frequently stated on social media, a sign of the times is that the most famous man in the world is a woman, Michelle Obama (Devesconi 2019). On the other hand, current myths' function is to naturalize the cultural - in other words, to make dominant cultural values, attitudes and beliefs seem entirely normal, self-evident, timeless, obvious, and commonsensical (Chandler 2007: 145). Once one has finished reading the book, the overriding feeling is that «Mi-

9 As reported by David Axlerod, Barack Obama's campaign manager, in his autobiography Believer: My Forty Years in Politics, Barack Obama initially believed this slogan might be too corny to be his tagline. When he asked Michelle's opinion, she simply stated: "Not corny". This convinced her husband to choose that slogan for his presidential campaign. 


\section{Ocula ${ }^{22}$}

Vol 21, No 22 (April 2020) • DOI: 10.12977/ocula2020-9

Flavia Cavaliere | Becoming Michelle, a Contemporary Cultural Icon. Decoding the Different Ways Leading from the South Side of Chicago to the White House

chelle - entranced, overwhelmed, concerned for her family's safety, and finding comfort in a McDonald's burger and a Target run - is more like the rest of us» (Saraiya 2018). When she seems genuinely surprised at having ended up living in a place whose "master suite was bigger than the entirety of the upstairs apartment my family had shared when I was growing up on Euclid Avenue» (305), she keeps reminding her readership that she is human, after all. Most of all, the frame semantics, frequently lexicalized as family, dignity, humanity, and convivial spirit, seem to translate Michelle's opinion that instead of «the opulence of the lifestyle [...] life was better when we could measure the warmth» (315). Since Freud theorized the process of identification - as a means whereby an individual develops his or her personality through idealizing and imitating a parent or other figure - the concept has been fruitfully applied to the appreciation of the arts. Identification with a character is one of the pleasures of reading, or of watching movies, or of seeing plays, though if it is where one's engagement with the work begins, it should not be where critical thought ends (Mead 2014).

Putting aside any strictly political implications about Michelle Obama as a high-profile public figure - which is far beyond the aim of this analysis -, when compared to many other celebrities who are similarly considered role models (maybe simply for their - too often unnatural - physical appearances), it cannot be denied that Michelle stands as a positive, ethical example. Her dynamic and self-assured image clearly demonstrates how «Confidence needs to be called from within» (284) and teaches how to recognize and fight against «the feelings of failure» (43). This possibly explains why, as maintained by Beyoncé Knowles-Carter in her above-mentioned tribute (2018) to Michelle Obama, the former First Lady has managed to become an undisputed role model for women, minorities and most of all the young generation all over the world, for whom she shines as a beacon of hope.

\section{References}

Abbamonte, Lucia; Cavaliere, Flavia

2006 "Lost in Translation: The Italian Rendering of UNICEF 'The State of the World's Children 2004' Report”, in Šarcevic, S. and Gotti, M. (eds.), Insights into Specialized Translation, Bern, Peter Lang, pp. 235-258.

Al Sibai, Noor

2017 “9 Yes We Can Memes \& Tweets That Define Obama’s Lasting Legacy”, Bustle. Available at: <https://www.bustle.com/p/9-yes-we-can-memes-tweets-thatdefine-obamas-lasting-legacy-29596>.

Anthony, Carl

2016 "First Ladies as Author", FirstLadies.org. Available at: <http://www. firstladies.org/blog/first-ladies-as-author>.

Axlerod, David

2015 Believer: My Forty Years in Politics, London, Penguin Press. 


\section{Ocula ${ }^{22}$}

Vol 21, No 22 (April 2020) • DOI: 10.12977/ocula2020-9

Flavia Cavaliere | Becoming Michelle, a Contemporary Cultural Icon. Decoding the Different Ways Leading from the South Side of Chicago to the White House

Barlaam, Riccardo

2019 "L'autobiografia di Michelle Obama è (quasi) la più venduta della storia", IlSole24Ore. Available at: <https://www.ilsole24ore.com/art/mondo/201903-29/l-autobiografia-di-michelle-obama-e-quasi-piu-venduta-storia-063953. shtml?uuid $=\mathrm{ABXUa2iB}>$.

Barthes, Roland

1957 Mythologies, New York, Hill \& Wang.

Barr, Sabrina

2019 "TIME 100 Michelle Obama, Chrissy Teigen, and Blasey Ford Ranked Among Most Influential People in the World", Independent. Available at: <https:// www.independent.co.uk/life-style/time-100-most-influential-michelleobama-chrissy-teigen-christine-blasey-ford-emilia-clarke-a8874506.html>.

Bauman, Zygmunt

2000 Liquid Modernity, Cambridge, Polity Press.

$\mathrm{BBC}$

2018 "Michelle Obama's memoir Becoming breaks sales record in 15 days", BBC.co.uk. Available at: <https://www.bbc.co.uk/news/world-uscanada-46407734>.

$\mathrm{BBC}$

2019 "Michelle Obama's memoir Becoming sells 10 million copies", BBC.co.uk Available at: <https://www.bbc.co.uk/news/business-47704987>.

Cavaliere, Flavia

2012 The Shaping of the News. How Information can be Molded by the Press, Roma, La Nuova Cultura.

Chandler, Daniel

2007 Semiotics: The Basics, New York, Routledge.

$\mathrm{CNN}$

2009 "Obama signs first presidential proclamation", CNN.com. Available at: <http://politicalticker.blogs.cnn.com/2009/01/20/obama-signs-firstpresidential-proclamation $>$.

Cobos, Mario Luis Rodrigues

1991 Universal Root Myths. Available at <http://www.silo.net>.

Davis, Julie

2016 "The Closer: Michelle Obama”, New York Times. Available at: <https://www. nytimes.com/2016/11/o6/us/politics/michelle-obama-2016-presidentialelection-first-lady.html>.

Devesconi, Francesca

2019 "Becoming, ecco perché la storia di Michelle Obama è da record", IlSole24Ore. Available at: <https://alleyoop.ilsole24ore.com/2019/o1/13/becominglautobiografia-michelle-obama $>$.

Fillmore, Charles; Baker, Collins

2001 "Frame Semantics for Text Understanding", in Proceedings of Word-Net and Other Lexical Resources Workshop, Pittsburgh, NAACL, pp. 59-64. 


\section{Ocula}

Vol 21, No 22 (April 2020) • DOI: 10.12977/ocula2020-9

Flavia Cavaliere | Becoming Michelle, a Contemporary Cultural Icon. Decoding the Different Ways Leading from the South Side of Chicago to the White House

Giddens, Anthony

2002 Runaway World: How Globalisation is Reshaping Our Lives, London, Profile Books.

Hannerz, Ulf

1996 Transnational Connections, London, Routledge.

Hillman, James

2007 Mythical Figures: Uniform Edition of the Writings of James Hillman, Washington, Spring Publications.

Hunston, Susan; Thompson, Geoff (eds.)

2000 Evaluation in Text: Authorial Stance and the Construction of Discourse, Oxford, Oxford University Press.

Iedema, Rick

2003 "Multimodality, Resemiotization: Extending the Analysis of Discourse as Multi-Semiotic Practice”, Visual Communication, 5, 1, pp. 29-57.

Jewitt, Carey

2009 "Multimodality and New Communication Technologies", in Jewitt, C. (ed.), The Routledge Handbook of Multimodal Analysis, London, Routledge.

Knowles-Carter Beyoncé

2019 "Michelle Obama", Time Magazine. Available at: < http://time.com/ collection/100-most-influential-people-2019/5567670/michelle-obama>.

Kress, Gunther

2003 Literacy in the New Media Age, London, Routledge.

Kress, Gunther; van Leeuwen, Theo

2006 Reading Images: The Grammar of Visual Design, London, Routledge.

Lakoff, George; Johnson, Mark

1980 Metaphors We Live By, Chicago, University of Chicago Press.

Lévi-Strauss, Claude

1955 “The Structural Study of Myth”, The Journal of American Folklore, 68, 270, pp. 428-444.

1963 Structural Anthropology, Oxford, Doubleday.

Lowe, John et al.

1998 "The Berkeley FrameNet Project”, Proceedings of the 17th International Conference on Computational Linguistics, pp.86-90.

Maalouf, Amin

1998 Les identités meurtrières, Paris, Grasset \& Fasquelle.

Martin, James; White, Peter

2007 The Language of Evaluation - Appraisal in English, New York, Palgrave Macmillan.

Mead, Rebecca

2014 "The Scourge of Relatability", The New Yorker. Available at: <https://www. newyorker.com/culture/cultural-comment/scourge-relatability>. 


\section{Ocula ${ }^{22}$}

Vol 21, No 22 (April 2020) • DOI: 10.12977/ocula2020-9

Flavia Cavaliere | Becoming Michelle, a Contemporary Cultural Icon. Decoding the Different Ways Leading from the South Side of Chicago to the White House

Moltedo, Guido

2015 "Yes, We Can. Come nacque (grazie a Michelle) lo slogan della fortuna di Obama”, Ytali.com. Available at: <https://ytali.com/2015/02/17/yes-we-cancome-nacque-grazie-a-michelle-lo-slogan-della-fortuna-di-obama $>$.

Obama, Michelle

2018 Becoming Michelle, New York, Crown.

Prior, Paul; Hengst, Julie (eds.)

2010 Exploring Semiotic Remediation as Discourse Practice, Basingstoke, Palgrave Macmillan.

Pestell, Ben; Palazzolo, Pietra (eds.)

2016 Translating Myth, New York, Routledge.

Saraiya, Sonia

2018 "In the Best Moments of Becoming, the Miracle of Michelle Obama Arises", Vanity Fair. Available at: <https://www.vanityfair.com/style/2018/11/ michelle-obama-becoming-book-review $>$.

St. Félix, Doreen

2018 "Michelle Obama's New Reign of Soft Power", The New Yorker. Available at: $<$ https://www.newyorker.com/books/page-turner/michelle-obamas-newreign-of-soft-power $>$.

Voloshinov, Valentin

1929/1973 Marxism and the Philosophy of Language, Cambridge, MA, Harvard University Press.

von Franz, Marie Louise

1989 I miti di creazione, Torino, Bollati Boringhieri.

Welsch, Wolfgang

1999 “Transculturality. The Puzzling Form of Cultures Today”, in Featherstone M. and Lash S. (eds.), Spaces of Culture: City, Nation, World, London, Sage, pp. 194-213.

Flavia Cavaliere è Professore associato di Lingua inglese e traduzione presso l'Università degli Studi di Napoli Federico II, Membro del Consiglio Direttivo del Centro Linguistico di Ateneo e Responsabile dell'Area Scientifica 'Multilinguismo' presso il Centro di Ricerca Intedipartimentale LUPT dell'Università degli Studi di Napoli Federico II. I suoi interessi di ricerca sono incentrati sui Translation Studies (in particolare sull'audiovisual translation), gli studi del multimodale con un approccio critico di analisi del discorso, la semiosi della comunicazione, il multilinguismo e l'uso di internet nella didattica delle lingue straniere. Fra i suoi volumi più recenti: The Shaping of the News (2012), Mediterranean Heritage in transit - (mis)representations via English (2016, con L. Abbamonte), Translation and Migration - Narratives of a Transition (2017), Euromosaic, a still open challenge (2019), Thought for Food (2019). 